\section{Counting the environmental cost of Japan's progress}

Tokyo

JAPAN's Environment Agency has passed a milestone in its history by making a selfconscious estimate of the effects of the phenomenon of Japan on the global environment. The agency's annual white paper, issued on $20 \mathrm{May}$, leaves few stones unturned. It deals with emissions of carbon dioxide, chlorofluorocarbons, nitrogen and sulphur oxides and acid rain, as well as tropical deforestation, trade in endangered species, and environmental problems in developing nations.

The view of Japan emerging is not especially flattering. Japan is a major source of chlorofluorocarbons, account ing for more than 10 per cent of world consumption. Much of the increase has been due to the use of chlorofluorocarbons in cleansing agents used by Japan's semiconductor industry.

The white paper also shows that Japan's emissions of carbon dioxide have grown much faster than those of western nations over the past two decades, now surpassing those of West Germany and Britain. And $p \mathrm{H}$ measurements by the agency indicate that acid rain is present throughout Japan,

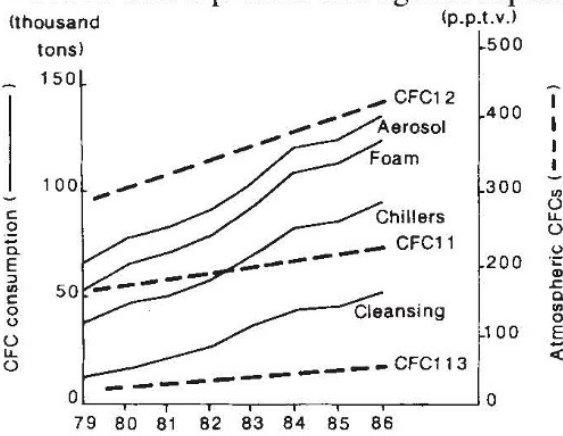

Year

Japan's annual consumption of CFCs by usage, and atmospheric levels of CFCs 11,12 and 113 . although the white paper depicts acid rain as predominantly a problem of Western Europe and North America. On the bright side, Japan's share of emissions of sulphur and nitrogen oxides has been held down by strong emission controls.

On trade, the report acknowledges that Japan is a major driving force behind the destruction of the world's tropical rainforests. Japan accounts for no less than 52 per cent of the world's imports of unprocessed tropical timber, the bulk of it from Malaysia.

Japan's influence as an importer of endangered species is openly discussed. The report says that imports of musk amount to $300 \mathrm{~kg}$ per year - entailing the destruction of more than 10,000 male musk deer a year. The deer is listed as an endangered species, but imports are allowed by classifying it as a "special reservation" species under the Washing- ton Convention. But the agency says it expects the deer to be excluded from the reservation list from next year.

On remedies, the white paper urges that Japan should take "actions worthy of its position as a great economic power". In particular, it says that last year's Montreal layer should be implemented "as soon as possible". (The Diet has already passed rushing to develop alternative chemicals.)

In extending aid to developing nations, the agency says, Japan should follow the example of the United States, Britain and West Germany and include environmenProtocol for the protection of the ozone legislation and Japanese companies are
Munich

West Germany's science advisory council, the Wissenschaftsrat, has come to the defence of the university system with a series of recommendations for the decades ahead. Its report, Recommendations on the perspectives of universities in the 1990s, may be a valuable antidote to the gloom, repeatedly echoed at last month's Westdeutsche Rektorenkonferenz, that over many years have diminished the once-lofty status of the university. The report is politically well-timed. Finance ministries in the Länder, which control university budgets, are seeking to cut corners

But the Wissenschaftsrat recommendations carry a "high degree of obligation", according to Diether Breitenbach, a member of the council who is also Minister of Culture, Education and Science in the Saarland. The report was unanimously approved on 20 May, with the support not only of professors but also of the finance ministries.

The council is particularly distraught that good research is increasingly concentrated at the national laboratories (of the Grossforschungsgemeinschaft, the MaxPlanck institutes and in industry rather than at universities. So the council recommends a sizeable increase of federal government support, which has fallen to 71 per cent of that in 1975, and which is expected to decline further. The federal government is also threatening to pay DM300 million less than originally planned for university construction projects in each of the next four years, but the the Länder in this case say they are willing to pay their full half-shares of the original costs of planned projects. too many students and too little money as they face the impending tax reform.

tal impact assessments in planning for aid projects. Japan has so far left impact assessment to the recipients. In Malaysia, for example, Japanese aid has been used to build logging roads without consideration for the consequent deforestation.

Over and above all this, the white paper repeatedly stresses the need to "revolutionize the consciousness of every member of the Japanese nation". People must be inculcated from childhood with an understanding "of the relationship of the environment with daily life". And everyone should follow the "lifestyle of an Earthling".

These are strong words for an agency with little political clout in Japan. It remains to be seen if they are translated into actions. Most of the changes called for lie beyond the agency's domain.

David Swinbanks

\title{
Light at end of the tunnel for Germany's universities?
}

The council fears that the trend for research to move out from universities will become even stronger, especially in applied fields such as electronics, which would further deepen the split between teaching and research, the union of which was the great triumph of the German university. The Wissenschaftsrat therefore urges that careful analysis should be given to proposals to found institutes outside universities to see whether their functions might not somehow be accomplished inside.

The Wissenschaftsrat says that university teaching must also be improved. It now takes students far too long to complete their studies (see Nature 333, 198; 1988). The average age for completing postdoctoral qualification (Habilitation) is 39.6 years, 10 years greater than in 1900 .

The Wissenschaftsrat also advocates more competition between universities, a new departure in West Germany. Thus it says that universities should be free to choose their students in popular fields such as medicine, instead of having them assigned by a central office. Even the sacrosanct bureaucratic structure of the universities may be affected. Breitenbach says there is "no guarantee" that the current university personnel structure will be maintained.

The head of the Wissenschaftsrat committee that prepared the recommendations, philosopher Jürgen Mittelstrass of the University of Constance, says that a country like West Germany poor in natural resources cannot afford to cut back on education and research. The general-secretary of the Wissenschaftsrat, Peter Kreyenberg, hopes that the recommendations will help West Germany to avoid following the "horror example" of Britain.

Steven Dickman 